\title{
ANALISIS FAKTOR-FAKTOR YANG MEMPENGARUHI KEPUTUSAN NASABAH UNTUK MENYIMPAN DANA PADA BANK SYARI'AH DI KOTA PURWOKERTO (Studi pada BRI Syariah dan Bank Muammalat Cabang Purwokerto)
}

\author{
Nita Despri Kartikasari \\ Universitas Muhammadiyah Purwokerto \\ Hermin Endratno \\ Universitas Muhammadiyah Purwokerto
}

\begin{abstract}
This study was conducted to analyze the factors that influence a client's decision to deposit funds in Islamic banks. In this study, the data used is primary data by questionnaire to customers of BRI Syariah and bank Muammalat Purwokerto with a sample of 156 reaponden. In the sampling method, the author uses purposive sampling method. The analysis used in this study using validity and reliability test, classic assumption test, multiple regression analysis, and hypothesis testing F-test, t-test and the coefficient of determination $\left(R^{2}\right)$.

The results showed that the characteristic variable bank, syariah factors, social class, reference groups, the role of family factors, factors perceived marketing stimuli simultaneously have a positive impact on the customer's decision to save in Islamic banks. Partial test results can be concluded that social class variables and variable marketing stimuli have a positive effect but not significant, while the variable characteristics of the bank, syariah factors, reference groups and family roles positive and significant impact on customer decisions. Concluded that all six variables are able to explain the customer's decision amounted to $44.5 \%$ (adjusted R-square value), while the remaining $55.5 \%$ is explained by other factors beyond the research
\end{abstract}

Keyword: Factor analysis, the customer's decision, Islamic banks

\section{ABSTRAK}

Penelitian ini dilakukan dengan tujuan untuk menganalisis faktor - faktor yang mempengaruhi keputusan nasabah untuk menyimpan dana di bank syariah. Dalam penelitian ini data yang digunakan adalah data primer dengan memberikan kuesioner kepada nasabah BRI Syariah dan bank Muammalat cabang Purwokerto dengan sampel sebanyak 156 reaponden. Dalam metode penentuan sampel ini, penulis menggunakan metode purposive sampling. Analisis yang digunakan dalam penelitian ini menggunakan uji validitas, uji reliabilitas, uji asumsi klasik, analisis regresi berganda, dan uji hipotesis uji F, uji t dan uji koefisien determinasi $\left(\mathrm{R}^{2}\right)$.

Hasil penelitian menunjukkan bahwa variabel karakteristik bank, faktor syariah, kelas sosial, kelompok referensi, faktor peran keluarga, faktor persepsi stimuli pemasaran secara simultan mempunyai pengaruh positif terhadap keputusan nasabah menabung di bank syariah. Hasil pengujian secara parsial dapat disimpulkan bahwa variabel kelas sosial dan variabel stimuli pemasaran berpengaruh positif namun tidak signifikan sedangkan variabel karakteristik bank, faktor syariah, kelompok referensi dan peran keluarga berpengaruh positif dan signifikan terhadap keputusan nasabah. Disimpulkan bahwa keenam variabel tersebut mampu menjelaskan keputusan nasabah sebesar 44,5\% (nilai adjusted $R$ square), sedangkan sisanya sebesar $55.5 \%$ dijelaskan oleh faktor lain diluar penelitian ini.

Kata kunci: Analisis faktor, keputusan nasabah, bank syariah.

\section{PENDAHULUAN}

Menurut penelitian Ghozali Maski (2010) s ecara umum calon nasabah yang akan menabung tentu memilih bank yang dapat memberikan keuntungan dan kemudahan. Setiap nasabah akan memperhatikan dan mempertimbangkan faktor-faktor tertentu untuk memutuskan menabung. Nasabah akan mempertimbangkan faktor-faktor tersebut untuk mencari kepuasan dalam menyimpan dananya di bank, karena bagaimanapun konsumen dalam perilakunya akan mencari kepuasan yang maksimal dalam memenuhi kebutuhannnya. Untuk itu dari sisi bank syariah harus dapat membaca 
peluang ini serta dapat segera mengidentifikasikan kebutuhan dan keinginan konsumen.

Kotler \& Keller (2006) dan Schiffman \& Kanuk (2007) mengidentifikasi bahwa stimuli pemasaran dan karakterisktik konsumen/lingkungan sosio-budaya mempengaruhi perilaku konsumen. Dampak stimuli pemasaran dapat dilakukan dengan mengukur persepsi nasabah terhadap nilai yang dirasakan (perceived value) atas stimuli pemasaran yang dilakukan perusahaan. Hal ini didasarkan pada model perilaku pembelian Schiffman dan Kanuk (2007) yang menyatakan bahwa dampak berbagai usaha pemasaran suatu perusahaan sebagian besar ditentuan oleh persepsi konsumen terhadap semua usaha ini. Karakterisktik konsumen atau lingkungan sosio-budaya berupa faktor kebudayaan (sub-budaya), termasuk agama; faktor kelas sosial, faktor kelompok referensi, dan faktor keluarga.

Menurut Kotler dan Keller (2006) kelas sosial merupakan salah satu dimensi kebudayaan. Dimensi sosial merupakan salah satu faktor karakteristik konsumen yang berpengaruh terhadap perilaku konsumen. Wells dan Prensky (1996) menyatakan bahwa kelas sosial mengacu pada posisi tertentu dalam struktur sosial dan ekonomi suatu masyarakat, yang didasarkan pada kriteria pendapatan, pendidikan, dan pekerjaan. Penelitian yang dilakukan LPM Universitas Hasanuddin (2003) menunjukkan bahwa salah faktor yang mempengaruhi masyarakat dalam mempergunakan jasa bank syariah, yaitu pendidikan dan penghasilan serta tingkat keuntungan.

Faktor peran dalam keluarga menyangkut bagaimana pengaruh seseorang dalam keluarganya. Schiffman dan Kanuk (2007) mengatakan bahwa dalam proses pengambilan keputusan dalam keluarga terdapat orang yang mempengaruhi para anggota keluarga lainnya dalam memberikan informasi mengenai suatu produk atau jasa. Dengan demikian, peran dalam keluarga sangat berperan dalam proses keputusan nasabah dalam kaitannya dengan pengembangan bank syariah.

\section{TINJAUAN PUSTAKA}

\section{Bank Syariah}

Menurut UU No. 21 Tahun 2008 tentang bank syariah, Bank Syariah adalah Bank yang menjalakan kegiatan usahanya berdasarkan Prinsip Syariah. (Soemitra, 2009)

Menurut Muhammad (2002) Bank syariah adalah bank yang beroperasi dengan tidak mengandalkan pada bunga. Bank islam atau bank tanpa bunga adalah lembaga keuangan atau perbankan yang operasional dan produknya dikembangkan berlandaskan pada al qur'an dan hadis Nabi Muhammad SAW atau dengan kata lain, bank syariah adalah lembaga keuangan yang usaha pokoknya memberikan pembiayaan dan jasa-jasa lainya dalam lalu lintas pembayaran serta peredaran uang yang pengoperasianya disesuaikan dengan prinsip syari'at Islam.

\section{Karakteristik Bank Syariah}

Siamat (2004) mengatakan bahwa kegiatan bank syariah dilandasi dengan memiliki konsekuensi duniawi dan ukhrawi karena seluruh kegiatan bank syariah dilakukan berdasarkan hukum islam. Oleh karena itu, karakteristik bank syariah dapat dijelaskan sebagai berikut menjauhkan dari riba serta menetapkan sistem bagi hasil (profit dan loss sharing)

Ali (2007) mengatakan bahwa riba secara bahasa bermakna ziyadah (tambahan). Dalam pengertian lain, secara linguistic riba juga berarti tumbuh dan membesar. Adapun menurut Antonio (2001) menjelaskan bahwa menurut istilah teknis, riba berarti pengambilan tambahan dari harta pokok atau modal secara batil. Hukum islam dengan tegas mengharamkan riba dalam segala bentuknya dan melarang mengambil riba apa pun jenisnya. Larangan supaya umat islam tidak melibatkan diri dengan riba bersumber dari berbagai surah dalam Al-Qur'an dan Hadist Rasulullah SAW.

Prinsip bagi hasil merupakan karakteristik umum dan landasan dasar bagi kegiatan operasional bank syariah secara keseluruhan. Bank syariah akan berfungsi sebagai mitra bagi para nasabah, baik yang akan menabung maupun yang akan meminjam dana. Dengan sistem bagi hasil, semua pihak kan menerima keuntungan yang adil, sehingga akan mendorong produktivitas, mendorong kelancaran arus barang/jasa, dan memelihara keseimbangan antara jumlah uang yang beredar dengan tersedianya barang dan jasa.

\section{Prinsip dan Bentuk Produk Bank Syari'ah}

Prinsip-prinsip syariah dalam kegiatan ekonomi dan keuangan, realisasi dari konsep syariah pada 
dasarnya sistem ekonomi atau perbankan syariah memiliki tiga ciri yang mendasar, yaitu (a) prinsip keadilan, (b) menghindari kegiatan yang dilarang, dan (c) memperhatikan aspek kemanfaatan. Ketiga ciri sistem perbankan syariah yang demikian tidak hanya memfokuskan perhatian pada diri sendiri untuk menghindari praktek bunga tetapi juga kebutuhan untuk menerapkan semua prinsip syariah dalam sistem ekonomi secara seimbang. (Zaenudin, 2007)

Bank syariah merupakan bank dengan prinsip dasar bagi hasil yang merupakan landasan utama dalam segala operasinya, baik dalam pengerahan dananya maupun dalam penyaluran dananya. Secara garis besar jenis kegiatan usaha bank syariah dapat dibagi ke dalam tiga kategori utama yaitu penghimpunan dana (funding), penyaluran dana (landing), dan pelayanan jasa.

\section{Daya Tarik Bank Syariah dan Perbedaan Menabung di Bank Syariah dengan Bank Konvensional}

Karena Bank Syari'ah tidak memberikan imbalan bunga kepada penyimpan dana, maka daya tarik bank syari'ah bagi penyandang dana (shohibul maal) adalah bila bank syari'ah dapat memberikan kembalian (return on investment) yang memadai. Selain itu perbedaan prinsip manajemen antara bank syari'ah dan bank konvensional dalam mengharmonisasikan kepentingan penyandang dana, pemegang saham dan pemakaian dana yaitu bila pada bank konvensional, kepentingan penyandang dana adalah diperolehnya imbalan berupa bunga simpanan yang tinggi, sedangkan kepentingan pemegang saham adalah diperolehnya spread yang optimal antara suku bunga simpanan dan suku bunga pinjaman (mengoptimalkan Interest Difference). (Antonio,1999)

\section{Model Perilaku Konsumen}

Mangkunegara (2005) mengemukakan model perilaku konsumen dapat didefinisikan sebagai suatu skema atau kerangka kerja yang disederhanakan untuk menggambarkan aktivitasaktivitas konsumen. Model perilaku konsumen dapat pula diartikan sebagai kerangka kerja atau sesuatu yang dalam mengambil keputusan pembeli.

Assael (2001) mendefinisikan pengambilan keputusan konsumen adalah proses merasa dan mengevaluasi informasi merek, mempertimbangkan bagaimana alternatif merek memenuhi kebutuhan konsumen dan memutuskan pada suatu merek. Menurut Assael (2001) ada dua pengaruh luas yang menentukan pilihan konsumen. Pengaruh pertama yaitu konsumen individu yang mana kebutuhan, persepsi merek karakteristik, dan sikap ke arah alternatif yang mempengaruhi pilihan merek. Pengaruh kedua dari pengambilan keputusan konsumen adalah lingkungan. Lingkungan pembelian konsumen digambarkan dengan budaya (norma dan nilai masyarakat), dengan sub-budaya (bagian dari masyarakat dengan norma-norma berbeda dan nilai dalam kehormatan tertentu) dan dengan kelompok bertatap muka (teman, anggota keluarga dan kelompok referensi).

Kotler dan Keller (2006) faktor yang mempengaruhi perilaku konsumen, yaitu kekuatan sosial budaya dan kekuatan psikologis yang keduanya terdiri dari dari beberapa indikator atau penunjuk yang bisa menjelaskan faktor kekuatan sosial dan dan factor

Kekuatan psikologis. Pertama, indikator dari faktor kekuatan budaya, antara lain: (a) faktor budaya; (b) faktor kelas social; (c) faktor kelompok anutan; dan (d) faktor keluarga. Kedua, kekuatan psikologis terdiri dari: (a) faktor pengalaman belajar; (b) faktor kepribadian; (c) faktor sikap dan keyakinan; dan (d) konsep diri atau self-concept

\section{METODE PENELITIAN}

Jenis penelitian ini dengan menggunakan metode survey. Objek penelitian yang digunakan dalam penelitian ini adalah faktor-faktor yang mempengaruhi keputusan nasabah untuk menyimpan dana pada bank umum syariah di kota Purwokerto. Populasi penelitian ini adalah nasabah giro, tabungan dan deposito pada bank Muammalat dan BRI syari'ah cabang Purwokerto. Alasan pemilihan bank tersebut karena 2 bank tersebut merupakan bank syariah yang relatif sudah lama beroperasi di kota Purwokerto. jumlah sampel yang diteliti adalah sebesar 156,11 responden. Untuk memudahkan penelitian maka penelitian mengambil sampel sebesar 156 responden

Metode pengambilan sampel dalam penelitian yaitu nonprobability sampling yaitu metode pemilihan dimana setiap anggota populasi mempunyai peluang/kesempatan yang tidak sama untuk menjadi anggota sampel. Teknik sampelnya yaitu dengan menggunakan sampling purposive, adalah teknik penentuan sampel dengan pertimbangan tertentu (Sugiono, 2008) Peneliti memandang bahwa individu-individu tertentu saja yang dapat mewakili (representative) karena menurut peneliti mereka 
yang dipilih yang mengerti tentang populasinya. Nasabah yang dijadikan sampel yaitu nasabah yang menyimpan dana pada bank Muammalat dan BRI Syariah cabang Purwokerto, dengan kriteria tingkat pendidikan minimal SMA untuk tujuan pemahaman ma teri kuesioner Analisis data yang dilakukan adalah analisis kuantitatif yang dinyatakan dengan angka - angka dan perhitungannya menggunakan metode statistik yang dibantu dengan program SPSS. Analisa data yang digunakan dalam penelitian ini yaitu pengujian asumsi klasik, analisis regresi berganda, dan uji hipotesis.

\section{HASIL PENELITIAN UJI}

\section{Asumsi Klasik}

\section{a. Uji Normalitas}

Uji normalitas bertujuan untuk menguji apakah dalam model regresi, variabel penggunaan atau residual memiliki distribusi normal atau tidak. Pengujian normalitas dilakukan dengan Uji Kolmogrov-Smirnov dan dinyatakan menyebar normal apakah hasil uji standardized residual memiliki nilai kolmogrov-smirnov atau asymp. sig. (2- tailed) lebih besar dari $\alpha(0,05)$. Adapun hasil uji normalitas dapat dilihat pada Tabel 4.1

Tabel 4.1 Hasil Uji Normalitas

One-Sample Kolmogorov-Smirnov Test

\begin{tabular}{|c|c|c|}
\hline & & Unstandardized Residual \\
\hline $\mathrm{N}$ & \multirow{7}{*}{$\begin{array}{l}\text { Mean } \\
\text { Std. } \\
\text { Deviation } \\
\text { Absolute } \\
\text { Positive } \\
\text { Negative }\end{array}$} & 156 \\
\hline \multirow{2}{*}{ Normal Parameters ${ }^{\mathrm{a}}$} & & .0000000 \\
\hline & & .54114735 \\
\hline \multirow[t]{3}{*}{ Most Extreme Differences } & & .091 \\
\hline & & .091 \\
\hline & & -.064 \\
\hline Kolmogorov-Smirnov Z & & 1.141 \\
\hline \multicolumn{2}{|l|}{ Asymp. Sig. (2-tailed) } & .148 \\
\hline
\end{tabular}

One-Sample Kolmogorov-Smirnov Test

\begin{tabular}{|c|c|c|}
\hline & & Unstandardized Residual \\
\hline $\mathrm{N}$ & \multirow{7}{*}{$\begin{array}{l}\text { Mean } \\
\text { Std. } \\
\text { Deviation } \\
\text { Absolute } \\
\text { Positive }\end{array}$} & 156 \\
\hline \multirow[t]{2}{*}{ Normal Parameters $^{\mathrm{a}}$} & & .0000000 \\
\hline & & .54114735 \\
\hline \multirow[t]{3}{*}{ Most Extreme Differences } & & .091 \\
\hline & & .091 \\
\hline & & -.064 \\
\hline Kolmogorov-Smirnov Z & & 1.141 \\
\hline \multicolumn{2}{|l|}{ Asymp. Sig. (2-tailed) } & .148 \\
\hline
\end{tabular}

Test distribution is Normal.

Berdasarkan tabel 4.37 diatas diketahui bahwa nitlai asymp. sig. (2-tailed) dari uji Kolmogorov-Smirnov untuk standardtized residual variable sebesar 0,148 lebih besar dari nilai yaitu 0,05 sehingga dapat disimpulkan bahwa data yang digunakan berdistribusi normal

\section{b. Uji Multikolinearitas}

Uji Multikolinieritas bertujuan untuk menguji apakah dalam model regresi ditemukan adanya korelasi antar variabel bebas (independen). Model regresi yang baik seharusnya tidak terjadi korelasi diantara variabel bebas (independen). Untuk mengetahui ada tidaknya multikolinearitas, dapat melihat nilai Variance Inflation Factor (VIF) dan nilai Tolerance dari variabel independen terhadap variabel dependen. Multikolinearitas terjadi apabila nilai VIF 
melebihi angka 10 dan nilai Tolerance kurang dari 0,05. Adapun hasil uji multikolinearitas dapat dilihat pada Tabel

Tabel 4.2 Hasil Uji Multikolinearitas

\section{Coefficients $^{\text {a }}$}

\begin{tabular}{|c|c|c|c|c|c|c|c|}
\hline Mod 1 & $\begin{array}{l}\text { Uns } \\
\text { Co }\end{array}$ & $\begin{array}{l}\text { ndardized } \\
\text { icients }\end{array}$ & $\begin{array}{l}\text { Standardize } \\
\mathrm{d}\end{array}$ & & & \multicolumn{2}{|c|}{$\begin{array}{l}\text { Collinearity } \\
\text { Statistics }\end{array}$} \\
\hline 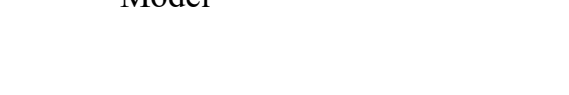 & B & $\begin{array}{l}\text { Std. } \\
\text { Error }\end{array}$ & Beta & $l$ & SIg. & Toleran & VIF \\
\hline 1 (Constant) & -.587 & .498 & & - & .241 & & \\
\hline Faktor Karakteristik Bank & .234 & .078 & .204 & 2.99 & .003 & .774 & 1.292 \\
\hline (X1) Faktor Syari'ah (X2) & .246 & .097 & .171 & 2.53 & .012 & .782 & 1.278 \\
\hline Faktor Kelas Sosial (X3) & .133 & .091 & .107 & 1.45 & .148 & .659 & 1.517 \\
\hline Faktor Kelompok Referensi & .179 & .087 & .194 & 2.05 & .042 & .401 & 2.496 \\
\hline (X4) Faktor Keluarga (X5) & .171 & .081 & .198 & 2.10 & .037 & .402 & 2.488 \\
\hline Faktor Persepsi Stimuli Pemasaran (X6) & .173 & .118 & .106 & $\begin{array}{l}1.46 \\
0\end{array}$ & .146 & .681 & 1.468 \\
\hline
\end{tabular}

Dependent Variable: Keputusan Nasabah (Y)

Berdasarkan hasil tabel 4.17 diatas diketahui bahwa dari keenam variabel nilai VIF faktor karakteristik bank (X1), faktor syari'ah (X2), faktor kelas sosial (X3), faktor kelompok referensi (X4), faktor keluarga (X5) maupun nilai VIF faktor persepsi stimuli pemasaran ( $\mathrm{X}_{6}$ ) masing-masing lebih kecil dari 10 dan nilai tolerance lebih besar dari 0,05 sehingga dapat disimpulkan tidak terjadi multikolinearitas dalam model regresi.

\section{c. Uji Heteroskedastisitas}

Uji Heteroskedastisitas bertujuan menguji apakah dalam model regresi terjadi ketidaksamaan variance dari satu residual pengamatan ke pengamatan lain. Uji Heteroskedastisitas dalam penelitian ini menggunakan uji glejser, dalam uji glejser model regresi tidak mengandung adanya heteroskedastiditas jika probabilitas signifikansinya diatas tingkat kepercayaan 5\% $(0,05)$.

Tabel 4.3 Hasil Uji Heteroskedastisitas

\begin{tabular}{|c|c|c|c|c|c|}
\hline \multirow[b]{2}{*}{ Model } & \multicolumn{2}{|c|}{$\begin{array}{l}\text { Unstandardized } \\
\text { Coefficients }\end{array}$} & \multirow{2}{*}{$\begin{array}{l}\text { Standardiz } \\
\text { ed } \\
\sim \\
\text { Beta }\end{array}$} & \multirow[b]{2}{*}{$\mathrm{T}$} & \multirow[b]{2}{*}{ Sig. } \\
\hline & $\mathrm{B}$ & Std. & & & \\
\hline 1 (Constant) & .894 & $\begin{array}{l}\text { Frror } \\
.322\end{array}$ & & 2.775 & .006 \\
\hline Faktor Karakteristik Bank & -.075 & .051 & -.132 & -1.494 & .137 \\
\hline (Y1) Eolytor Cyonigh (Y) & -.027 & .063 & -.037 & -.425 & .672 \\
\hline$(X 1)$ Faktor Syarı'ah (X2) & -.042 & .059 & -.067 & -.704 & .483 \\
\hline Faktor Kelas Sosial (X3) & -.086 & .056 & -.187 & -1.529 & .128 \\
\hline Faktor Kelompok Referensi & -.032 & .053 & -.075 & -.617 & .538 \\
\hline (X4) Faktor Keluarga (X5) & .122 & .076 & .150 & 1.596 & .113 \\
\hline
\end{tabular}

Dependent Variable: ABS_1

Berdasarkan tabel 4.18 diatas menunjukan bahwa seluruh variabel dari faktor karakteristik bank $\left(\mathrm{X}_{1}\right)$, faktor syari'ah $\left(\mathrm{X}_{2}\right)$, faktor kelas sosial $\left(\mathrm{X}_{3}\right)$, faktor kelompok 
referensi $\left(\mathrm{X}_{4}\right)$, faktor keluarga $\left(\mathrm{X}_{5}\right)$ maupun dari faktor persepsi stimuli pemasaran $\left(\mathrm{X}_{6}\right)$ masing-masing memiliki signifikansi diatas 5\% atau lebih besar 0,05. Berdasarkan bukti tersebut, maka dapat disimpulkan bahwa tidak terdapat heteroskedastisitas dalam model regresi.

\section{Metode Analisis Data}

\section{a. Analisis Regresi Linier Berganda}

Pengujian signifikansi pengaruh variabel bebas terhadap variabel terikat dalam penelitian ini dilakukan dengan teknik analisis regresi berganda. Hasil perhitungan analisis regresi berganda dapat dilihat pada tabel koefisien berikut:

Tabel 4.4 Hasil Analisis Regresi

\begin{tabular}{|l|r|r|r|r|r|}
\hline \multirow{2}{*}{ Model } & \multicolumn{2}{|c|}{$\begin{array}{c}\text { Unstandardized } \\
\text { Coefficients }\end{array}$} & $\begin{array}{c}\text { Standardized } \\
\text { Coefficients }\end{array}$ & & \\
\cline { 2 - 6 } & \multicolumn{1}{c|}{ B } & Std. Error & \multicolumn{1}{|c|}{ Beta } & \multicolumn{1}{c|}{ S } & Sig. \\
\hline (Constant) & -.587 & .498 & & -1.17 & .241 \\
Faktor Karakteristik Bank (X1) & .234 & .078 & .204 & 2.995 & .003 \\
Faktor Syari'ah (X2) & .246 & .097 & .171 & 2.532 & .012 \\
Faktor Kelas Sosial (X3) & .133 & .091 & .107 & 1.454 & .148 \\
Faktor Kelompok Referensi (X4) & .179 & .087 & .194 & 2.056 & .042 \\
Faktor Keluarga (X5) & .171 & .081 & .198 & 2.101 & .037 \\
Faktor Persepsi Stimuli Pemasaran (X6) & .173 & .118 & .106 & 1.460 & .146 \\
\hline
\end{tabular}

\section{Coefficients $^{\mathrm{a}}$}

Dependent Variable: Keputusan Nasabah (Y

Berdasarkan Tabel 4.19, dapat dibuat persamaan regresi berganda sebagai berikut: $\mathrm{Y}=-0,587+0,234 \mathrm{X}_{1}+0,246 \mathrm{X}_{2}+0,133 \mathrm{X}_{3}+0,179 \mathrm{X}_{4}+0,171 \mathrm{X}_{5}+0,173 \mathrm{X}_{6}$

Berdasarkan persamaan tersebut dapat dijelaskan beberapa hal:

a) Koefisien regresi sebesar 0,234 yang berarti faktor karakteristik bank mempunyai pengaruh positif terhadap keputusan nasabah dalam menyimpan dananya di bank syari'ah Purwokerto, atau secara fungsional dapat dinyatakan jika faktor karakteristik bank meningkat sebesar satu satuan, maka akan dapat meningkatkan keputusan nasabah dalam menyimpan dananya di bank syari'ah Purwokerto sebesar 0,234 satuan dengan menganggap variabel lain tetap

b) Koefisien regresi sebesar 0,246 yang berarti faktor syari'ah mempunyai pengaruh positif terhadap keputusan nasabah dalam menyimpan dananya di bank syari'ah Purwokerto, atau secara fungsional dapat dinyatakan jika faktor syari'ah meningkat sebesar satu satuan, maka akan dapat meningkatkan keputusan nasabah dalam menyimpan dananya di bank syari'ah Purwokerto sebesar 0,246 satuan dengan menganggap variabel lain tetap.

c) Koefisien regresi sebesar 0,133 yang berarti faktor kelas sosial mempunyai pengaruh positif terhadap keputusan nasabah dalam menyimpan dananya di bank syari'ah Purwokerto, atau secara fungsional dapat dinyatakan jika faktor kelas sosial meningkat sebesar satu satuan, maka akan dapat meningkatkan keputusan nasabah dalam menyimpan dananya di bank syari'ah Purwokerto sebesar 0,133 satuan dengan menganggap variabel lain tetap.

d) Koefisien regresi sebesar 0,179 yang berarti faktor kelompok referensi mempunyai pengaruh positif terhadap keputusan nasabah dalam menyimpan dananya di bank syari'ah Purwokerto, atau secara fungsional dapat dinyatakan jika faktor kelompok referensi meningkat sebesar satu satuan, maka akan dapat meningkatkan keputusan nasabah dalam 
menyimpan dananya di bank syari'ah Purwokerto sebesar 0,179 satuan dengan menganggap variabel lain tetap.

e) Koefisien regresi sebesar 0,171 yang berarti faktor keluarga mempunyai pengaruh positif terhadap keputusan nasabah dalam menyimpan dananya di bank syari' ah Purwokerto, atau secara fungsional dapat dinyatakan jika faktor keluarga meningkat sebesar satu satuan, maka akan dapat meningkatkan keputusan nasabah dalam menyimpan dananya di bank syari'ah Purwokerto sebesar 0,171 satuan dengan menganggap variabel lain tetap

f) Koefisien regresi sebesar 0,173 yang berarti faktor persepsi stimuli pemasaran mempunyai pengaruh positif terhadap keputusan nasabah dalam menyimpan dananya di bank syari'ah Purwokerto, atau secara fungsional dapat dinyatakan jika faktor persepsi stimuli pemasaran meningkat sebesar satu satuan, maka akan dapat meningkatkan keputusan nasabah dalam menyimpan dananya di bank syari'ah Purwokerto sebesar 0,173 satuan dengan menganggap variabel lain tetap..

\section{b. Pengujian secara Simultan (Uji F)}

Uji F ini digunakan untuk menguji pengaruh variabel faktor karakteristik bank, faktor syari'ah, faktor kelas sosial, faktor kelompok referensi, faktor keluarga dan faktor persepsi stimuli pemasaran berpengaruh secara bersama-sama terhadap keputusan nasabah, menggunakan uji F. Hasil uji F dapat dilihat pada tabel 4.20:

\section{Tabel 4.41 Hasil Uji F}

\begin{tabular}{|c|c|c|c|c|c|}
\hline \multicolumn{6}{|c|}{ ANOVA $^{b}$} \\
\hline Model & Sum of Squares & Df & Mean & $\mathrm{F}$ & $\mathrm{S}$ \\
\hline Regression & 39.740 & 6 & 6.623 & 21.742 & .000 \\
\hline Residual & 45.390 & 149 & .305 & & \\
\hline Total & 85.130 & 155 & & & \\
\hline
\end{tabular}

a) Predictors: (Constant), Faktor Persepsi Stimuli Pemasaran (X6), Faktor Karakteristik Bank (X1), Faktor Kelompok Referensi (X4), Faktor Syari'ah (X2), Faktor Kelas Sosial (X3), Faktor Keluarga (X5)

b) Dependent Variable: Keputusan Nasabah (Y)

Berdasarkan tabel diatas menunjukkan nilai $\mathrm{F}$ hitung sebesar 21,742 lebih besar dari nilai $\mathrm{F}$ tabel dengan $\mathrm{df}=(\mathrm{k}-1)$ dan $(\mathrm{n}-\mathrm{k})$ sebesar 2,16. Dengan demikian, maka model regresi yang terbentuk dinyatakan tepat (goodness of fit). Hasil uji $\mathrm{F}$ tersebut juga menunjukkan bahwa faktor karakteristik bank, faktor syari'ah, faktor kelas sosial, faktor kelompok referensi, faktor keluarga dan faktor persepsi stimuli pemasaran secara bersama-sama (simultan) mempunyai pengaruh yang signifikan terhadap keputusan nasabah.

\section{c. Pengujian secara Parsial (Uji t)}

Pengujian ini bertujuan untuk menguji pengaruh variabel bebas terhadap variabel terikat secara terpisah. Pengujian signifikansi pengaruh faktor karakteristik bank, faktor syari'ah, faktor kelas sosial, faktor kelompok referensi, faktor keluarga dan faktor persepsi stimuli pemasaran terhadap keputusan nasabah dalam menyimpan dananya di bank syari'ah Purwokerto secara parsial dilakukan uji t. Dengan menggunakan tingkat kesalahan $(\alpha)=$ 0,05 dan degree of freedom $(\mathrm{n}-\mathrm{k})$, dimana $\mathrm{n}=156$ dan $\mathrm{k}=7$ untuk pengujian satu sisi (one tiled) diketahui nilai t tabel sebesar 1,655. Adapun dari analisis regresi linear berganda pada tabel 4.19 diperoleh hasil bahwa nilai t hitung faktor karakteristik bank $\left(\mathrm{X}_{1}\right)$ sebesar 2,995, nilai t hitung faktor syari'ah (X2) sebesar 2,532, nilai $t$ hitung faktor kelas sosial (X3) sebesar 1,454, nilai t hitung faktor kelompok referensi (X4) sebesar 2,056, nilai t hitung faktor keluarga (X5) sebesar 2,101 dan nilai $t$ hitung faktor persepsi stimuli pemasaran $\left(\mathrm{X}_{6}\right)$ sebesar 1,460 . 


\section{Pembahasan}

a. Pengaruh faktor farakteristik bank terhadap keputusan nasabah dalam menyimpan dana di bank syari'ah Purwokerto.

Hasil penelitian ini berhasil membuktikan bahwa faktor karakteristik bank berpengaruh positif dan signifikan terhadap keputusan nasabah dalam menyimpan dananya di bank syari'ah Purwokerto. Artinya, semakin baik persepsi nasabah terhadap karakteristik bank, maka akan semakin tinggi minat nasabah untuk menyimpan dananya di bank syari'ah Purwokerto. Hasil penelitian ini sejalan dengan hasil penelitian sebelumnya yang dilakukan oleh Ghozali Maski (2010) yang membuktikan bahwa faktor karakteristik bank berpengaruh positif dan signifikan terhadap keputusan menabung nasabah. Responden yang berpendapat bahwa bank syari'ah mengikuti syariah agama islam cenderung akan memilih bank syari'ah sebagai tempat menyimpan dananya, responden yakin akan penerapan sistem bagi hasil, produk-produk yang islami juga menambah kecenderungan untuk menabung di bank syari'ah. Dalam hal ini bagi masyarakat bank syari'ah mengadopsi sistem keunikan produk yang islami serta bagi hasil menjadi jasa andalan bank syari'ah.

b. Pengaruh faktor syari'ah terhadap keputusan nasabah dalam menyimpan dana di bank syari'ah Purwokerto

Hasil penelitian ini membuktikan bahwa faktor syari'ah berpengaruh positif dan signifikan terhadap keputusan nasabah dalam menyimpan dananya di bank syari'ah Purwokerto. Artinya, semakin baik persepsi nasabah terhadap syari'ah, maka akan semakin tinggi minat mereka untuk menyimpan dananya di bank syari'ah Purwokerto. Hasil penelitian ini sejalan dengan hasil penelitian sebelumnya yang dilakukan oleh Rivai (2007) dan BI dengan IPB (2004) memberikan informasi tentang pertimbangan dominan responden di dalam memilih dan menyimpan dana pada bank syariah, yaitu faktor keyakinan bahwa bunga bank bertentangan dengan agama serta kesesuaian dengan syariat islam. Unsur halal dalam perbankan syari'ah merupakan hal yang menjadi titik tumpu sehingga masyarakat dapat secara tenang menggunakan produk syari'ah terhindar dari hal-hal yang bertentangan dari agama (syari'ah) artinya, bahwa keputusan menabung adalah untuk meninggalkan riba dan menggunakan jasa bank syariah dengan konsep sesuai syari'at.

c. Pengaruh faktor kelas sosial terhadap keputusan nasabah dalam menyimpan dana di bank syari'ah Purwokerto

Hasil penelitian ini menunjukkan bahwa faktor kelas sosial berpengaruh positif namun tidak signifikan terhadap keputusan nasabah dalam menyimpan dananya di bank syari'ah Purwokerto. Hasil penelitian ini berbeda dengan hasil penelitian sebelumnya yang dilakukan oleh Nasir (2010) yang menyimpulkan bahwa variabel faktor kelas sosial mempunyai pengaruh langsung yang signifikan terhadap faktor informasi keputusan nasabah untuk menyimpan dana pada bank syariah. Kelas sosial merupakan dimensi kebudayaan yang mengacu pada posisi tertentu dalam struktur sosial dan ekonomi suatu masyarakat misalnya, pada kriteria pendapatan, pendidikan dan pekerjaan, nilai prestise dalam masyarakat dan mobilitas keadaan masyarakat dalam lingkungan sosial. Responden bank syariah mayoritas (berpenghasilan menengah Rp.2.000.000 - Rp.3.000.000) sehingga responden akan memposisikan dirinya sebagai kelompok sosial tertentu yang akan cenderung memilih tempat transaksi yang sesuai dengan kepribadian dan kelas sosialnya. Dalam kaitanya mengenai wawancara dengan nasabah saat pengisian kuesioner, pernyataan responden yang menyatakan faktor penghasilan besar tidak diikuti untuk memutuskan menabung di bank syariah melainkan ada faktor lain seperti lebih mengenai syariah.

d. Pengaruh faktor kelompok referensi terhadap keputusan nasabah dalam menyimpan dana di bank syari'ah Purwokerto

Hasil penelitian ini membuktikan bahwa faktor kelompok referensi berpengaruh positif dan signifikan terhadap keputusan nasabah dalam menyimpan dananya di bank syari'ah Purwokerto. Artinya, semakin tinggi pengaruh kelompok referensi, maka akan semakin tinggi minat nasabah untuk menyimpan dananya di bank syari'ah Purwokerto. Hasil penelitian ini sejalan dengan hasil penelitian sebelumnya yang dilakukan oleh Nasir (2010) yang menyimpulkan bahwa menunjukkan bahwa variabel kelompok referensi mempunyai pengaruh langsung yang signifikan terhadap faktor informasi keputusan nasabah untuk menyimpan dana pada bank syariah. Temuan dalam penelitian ini dapat dijelaskan bahwa informasi yang diberikan 
oleh kelompok formal maupun non-formal tentang bank syariah berpengaruh langsung pada informasi keputusan nasabah yang pada akhirnya mereka menyimpan dananya pada bank syariah. Responden bank syari'ah akan cenderung mempertimbangkan keputusan menabung karena pengaruh dari sebuah kelompok sosial, dimana dalam sebuah kelompok sosial terdapat pelopor yang dijadikan anutan sehingga dapat mempengaruhi perilaku anggotanya termasuk informasi mengenai menggunakan jasa perbankan syariah.

e. Pengaruh faktor keluarga terhadap keputusan nasabah dalam menyimpan Dana di bank syari'ah Purwokerto

Hasil penelitian ini menemukan bukti bahwa faktor keluarga berpengaruh positif dan signifikan terhadap keputusan nasabah dalam menyimpan dananya di bank syari'ah Purwokerto. Artinya, semakin besar pengaruh keluarga dalam merekomendasikan bank syari'ah, maka akan semakin tinggi minat nasabah untuk menyimpan dananya di bank syari'ah Purwokerto. Hasil penelitian ini sejalan dengan hasil penelitian sebelumnya yang dilakukan oleh Subchan Yahya (2010) dan Nasir (2010) yang menyimpulkan bahwa keluarga merupakan salah satu faktor yang dipertimbangkan oleh nasabah, peran dalam keluarga sangat berperan dalam proses keputusan nasabah dalam kaitannya dengan pengembangan bank syariah. Artinya responden dalam memutuskan untuk menabung di bank syari'ah merupakan dorongan dari keluarga yang merupakan organisasi islam yang mendominasi pengetahuan mengenai bank syari'ah hingga memutuskan untuk memilih menggunakan produk bank syariah misalnya, menabung.

f. Pengaruh faktor persepsi stimuli pemasaran terhadap keputusan nasabah dalam menyimpan dana di bank syari'ah Purwokerto

Selanjutnya, hasil penelitian ini menunjukkan bahwa faktor persepsi stimuli pemasaran berpengaruh positif namun tidak signifikan terhadap keputusan nasabah dalam menyimpan dananya di bank syari'ah Purwokerto. Artinya, semakin tinggi persepsi nasabah terkait dengan stimuli pemasaran tidak selalu diikuti dengan semakin tingginya minat nasabah untuk menyimpan dananya di bank syari'ah Purwokerto. Hasil penelitian ini berbeda dengan hasil penelitian sebelumnya yang dilakukan oleh Subchan Yahya (2010) yang menyimpulkan bahwa stimuli pemasaran yaitu produk, fasilitas dan pelayanan, lokasi, promosi dan merek merupakan faktor-faktor yang dipertimbangkan oleh nasabah dalam menggunakan Jasa Bank Syariah. Semakin tinggi persepsi nasabah dengan stimuli pemasaran tidak selalu diikuti semakin tinggi minat nasabah, pertimbangan dalam penggunaan fasilitas dari bank syari'ah juga mempengaruhi responden dalam menabung. Dalam hal ini adanya fasilitas yang semakin baik justru mengurangi responden menabung. Hal ini karena responden menganggap semakin tinggi fasilitas maka semakin tinggi biaya/ongkos yang digunakan dalam fasilitas tersebut. Sehingga responden lebih mementingkan faktor lain dalam menabung di bank syariah.

g. Pengaruh secara simultan antara karakteristik bank, faktor syariah, faktor kelas sosial, faktor kelompok referensi, faktor keluarga, faktor stimuli pemasaran terhadap keputusan nasabah dalam menyimpan dana di bank syari'ah Purwokerto

Hasil pengujian hipotesis ketujuh tentang pengaruh karakteristik bank, faktor syariah, faktor kelas sosial, faktor kelompok referensi, faktor keluarga, faktor stimuli pemasaran terhadap keputusan nasabah, hasil pengujian hipotesis kelima didapat hasil bahwa keenamt variabel tersebut memiliki pengaruh secara simultan terhadap keputusan nasabah. Hal ini dapat dilihat dari nilai signifikan sebesar $0,000<0,05$ atau $F$ hitung $>F$ tabel 21,742 $>2,16$. Hasil penelitian ini sejalan dengan penelitian Nasir (2010), bahwa secara bersama-sama faktor syariah, sosial, kelompok referensi, stimuli pemasaran, proses keputusan nasabah berpengaruh secara siginifikan terhadap keputusan nasabah. Hal tersebut didukung oleh pendapat Kotler dan Keller (2006) dan Schiffman dan Kanuk (2007) mengemukakan bahwa bahwa terdapat beberapa faktor yang relevan dan mempengaruhi perilaku nasabah bank syariah dalam menggunakan produk penghimpunan dana bank syariah.

Dari keenam variabel bebas diatas, variabel faktor syari'ah memiliki koefisien b yang paling besar. Dengan demikian variabel faktor syari'ah mempunyai pengaruh yang paling dominan terhadap keputusan nasabah menabung di bank syari'ah. Hal ini berhubungan dengan faktor dari karakteristik bank syari'ah sendiri yang mengadopsi sistem keunikan produk dan bagi hasil yang islami, juga dari faktor kelompok referensi dan keluarga dari organisasi muslim. Dari beberapa alasan tersebut dapat disimpulkan seorang nasabah akan memutuskan menabung di bank 
syari'ah karena nasabah yakin akan manfaat islami dari investasi halal dan pengaruh dari lingkungan sosialnya yang mendukung keputusan memilih menggunakan jasa perbankan syariah.

\section{KESIMPULAN DAN SARAN}

\section{Kesimpulan}

Berdasarkan hasil penelitian dan perhitungan dengan metode analisis yang digunakan, maka dapat disimpulkan sebagai berikut:

1. Variabel karakteristik bank memiliki pengaruh positif dan signifikan terhadap keputusan nasabah. Berdasarkan nilai $t$ hitung sebesar 2,995 lebih besar dari t tabel 1,655 dengan taraf signifikan hasil sebesar 0,003 lebih kecil dari 0,05, yang berati bahwa hipotesis dalam penelitian

2. Variabel faktor syariah memiliki pengaruh positif dan signifikan terhadap keputusan nasabah. Berdasarkan nilai t hitung sebesar 2,532 lebih besar dari t tabel 1,655 dengan taraf signifikan hasil sebesar 0,012 lebih kecil dari 0,05, yang berati bahwa hipotesis dalam penelitian ini diterima.

3. Faktor kelas sosial mempunyai pengaruh yang positif namun tidak signifikan terhadap keputusan nasabah dalam menyimpan dananya di bank syari'ah Purwokerto. Berdasarkan nilai t hitung sebesar 1,454 kurang dari t tabel 1,655 dengan taraf signifikan hasil sebesar 0,148 lebih kecil dari 0,05, yang berati bahwa hipotesis dalam penelitian ini ditolak.

4. Variabel kelompok referensi memiliki pengaruh positif dan signifikan terhadap keputusan nasabah. Berdasarkan nilai t hitung sebesar 2,056 lebih besar dari t tabel 1,655 dengan taraf signifikan hasil sebesar 0,042 lebih kecil dari 0,05, yang berati bahwa hipotesis dalam penelitian ini diterima.

5. Variabel faktor keluarga memiliki pengaruh positif dan signifikan terhadap keputusan nasabah. Berdasarkan nilai $t$ hitung sebesar 2,101 lebih besar dari $t$ tabel 1,655 dengan taraf signifikan hasil sebesar 0,037 lebih kecil dari 0,05, yang berati bahwa hipotesis dalam penelitian ini diterima.

6. Faktor persepsi stimuli mempunyai pengaruh yang positif namun tidak signifikan terhadap keputusan nasabah dalam menyimpan dananya di bank syari'ah Purwokerto. Berdasarkan nilai $\mathrm{t}$ hitung sebesar 1,460 kurang dari t table 1,655 dengan taraf signifikan hasil sebesar 0,146 lebih kecil dari 0,05, yang berati bahwa hipotesis dalam penelitian ini ditolak.

7. Variabel karakteristik bank, faktor syariah, faktor kelas sosial, faktor kelompok referensi, faktor keluarga dan faktor persepsi stimuli pemasaran berpengaruh secara simultan terhadap keputusan nasabah, hal ini dapat dilihat dari nilai $\mathrm{F}$ hitung sebesar 21,742 lebih besar dari $\mathrm{F}$ tabel 2,16 dengan taraf signifikansi hasil sebesar 0,000 lebih kecil dari 0,05, yang berarti bahwa secara simultan hipotesis penelitian ini diterima.

\section{Saran}

Berdasarkan hasil penelitian dan kesimpulan yang telah disajikan maka selanjutnya peneliti menyampaikan saran-saran yang kiranya dapat memberikan manfaat kepada pihak- pihak yang terkait atas hasil penelitian ini.

\section{Bagi manajemen perbankan}

a. Dalam variabel karakteristik bank, indikator bagi hasil memiliki pengaruh terhadap keputusan nasabah menabung di bank syariah. Oleh karena itu pihak bank syari'ah hendaknya tetap mempertahankan kebijakan dalam penerapan persentase bagi hasil yang cukup tinggi, sehingga nasabah tetap memilih bank syariah sebagai alternatif utama dalam menabung.

b. Hal penting dan tidak boleh dilupakan adalah bahwa sebuah bisnis Islami, khususnya bank syari'ah idealisme produk atau kinerja berdasarkan syari'ah Islam yang harus terus menerus dipertahankan dan ditingkatkan. Hal inilah yang membedakan antara perbankan syari'ah dengan perbankan konvensional.

c. Pada penelitian ini variabel persepsi stimuli berpengaruh namun tidak signifikan terhadap 
kepuasan nasabah. Persepsi terbentuk berdasarkan informasi yang di terima oleh seseorang. Semakin positif informasi yang dimiliki akan semakin bagus. Walaupun persepsi bisa dipengaruhi oleh hal lain, penting bagi pihak bank untuk membentuk persepsi positif kepada nasabah maupun calon nasabah.

d. Terkait pelayanan, fasilitas, dan pemasaran untuk ditingkatkan kepada staf marketing dan costumer service yang secara langsung berinteraksi dengan nasabah, diharapkan lebih memperbanyak kantor kas untuk memenuhi kebutuhan masyarakat serta memperkenalkan produk funding dalam promosi baik di media cetak maupun media online.

\section{Bagi penelitian selanjutnya}

a. Penelitian selanjutnya diharapkan dapat memperluas penelitian dengan menambahkan variabel penelitian dengan variabel lain yang dapat mempengaruhi keputusan nasabah dalam menabung di bank syari'ah

b. Penelitian selanjutnya dapat menambah objek penelitian dengan mengambil populasi responden pada bank syariah lain yang ada di kota Purwokerto

\section{DAFTAR PUSTAKA}

Ali Zaenuddin. 2007. Hukum Perbankan Syariah, Sinar Grafika, Jakarta

Almossawi, M. 2001. Bank Selection Criteria Employed by College Student in Bahrain. The International Journal of Bank Marketing; 19, 3; ABI/INFORM Global, pg 115.

Arikunto, Suharsimi. (2006). Prosedur Penelitian: Suatu Pendekatan Praktik (Revisi VI). Jakarta: Rineka Cipta.

Assael, Henry. 2001. Consumer Behavior 6 th Edition.New York: Thomson- Learning..

Antonio, M.S 2001. Bank Syariah: Dari Teori ke Praktik. Badan Penerbit Gema Insani, Jakarta

Bank Indonesia dan Institut Pertanian Bogor. 2004. Penelitian Potensi, Preferensi, dan Perilaku Masyarakat Terhadap Bank Syariah di Wilayah Kalimantan Selatan. Ringkasan Eksekutif Hasil Penelitian. Bank Indonesia, Jakarta.

Bank Indonesia dan Institut Pertanian Bogor. 2004a. Potensi, Preferensi, dan Perilaku Masyarakat Terhadap Bank Syariah; Studi Pada Wilayah Propinsi Sumatera Selatan. Ringkasan Eksekutif Hasil Penelitian. Bank Indonesia, Jakarta.

Ghozali Maski. 2010, Analisis keputusan nasabah menabung: pendekatan komponen dan model logistik studi pada bank syari'ah di Malang. Volume. 4 No. 1 Malang.

Ghozali, I. 2001. Aplikasi Analisis Multivariate dengan Program SPSS. Badan Penerbit Universitas Diponegoro, Semarang.

Ghozali, Imam. 2013. Aplikasi Analisis Multivariate dengan program IBM SPSS 21. Badan penerbit Universitas Diponegoro, Semarang.

Karim, A.A. 2006. Bank Islam, Analisis Fiqih dan Keuangan. PT Raja Grafindo Persada, Jakarta.

Kotler, P., dan Keller, K.L. 2006. Manajemen Pemasaran. 12e. Badan Penerbit Indeks.

Mangkunegara, A.P. 2002. “Perilaku Konsumen”. Badan Penerbit Refika, Jakarta

Nasir. 2010, Analisis faktor-faktor yang mempengaruhi keputusan nasabah untuk menyimpan dana pada bank syariah di kota makasar.

Rivai, H.A. 2007. Identifikasi Faktor Penentu Keputusan Konsumen dalam Memilih Jasa Perbankan: Bank Syariah vs Bank Konvensional. Center for Banking Research-Andalas University dan Bank 
Jurnal Manajemen dan Bisnis MEDIA EKONOMI Volume XVI, NO. 2 Juli 2016

Indonesia.

Schiffman, L.G. dan Kanuk, L.L. 2007. Perilaku Konsumen 7th ed. Terjemahan. PT Indeks, Jakarta.

Siamat, Dahlan. 2004. Manajemen Lembaga Keuangan, Edisi Keempat, Lembaga Penerbit Fakultas Ekonomi Universitas Indonesia.

Setiaji N.J .2008. Perilaku Konsumen: Konsep dan Implikasi untuk Strategi dan Penelitian Pemasaran. Kencana, Jakarta

Sugiyono. 2008. Metode Penelitian Bisnis. Alfabeta, Bandung.

Sugiyono. 2013. Metode Penelitian Pendidikan Pendekatan Kuantitatif, Kualitatif, danR\&D. Bandung: ALFABETA

Suharyadi, Purwanto S.K. 2004. Statistik Untuk Ekonomi Keuangan Modern Buku 2 Jakarta: Salemba Empat.

Umar, Husein. 2000. Metode Penelitian untuk Pemasaran. Gramedia Pustaka Utama, Jakarta

Wells, W.D. dan Prensky, D. 1996. Consumer Behavior. John Wiley \& Sons, Inc., Canada.

Wibowo, E. dan Widodo, U.H. 2005. Mengapa Memilih Bank Syariah? Ghalia Indonesia, Bogor.

Yayan Fauzi .2010. Faktor-faktor yang mempengaruhi nasabah menabung di perbankan syariaH (study kasus pada bank BNI syariah kantor cabang Yogyakarta). Skripsi. UIN Yogyakarta 